\title{
QUENTIN SKINNER ON ENCOUNTERING THE PAST.
}

PETRI KOIKKALAINEN AND SAMI SYRJÄMÄKI: When and how
did you first become interested in political theory and its history?

QUENTIN SKINNER: Before trying to answer, may I first say how deeply grateful I am to you for this interview, and for showing such a generous interest in my work. I shall of course try to answer your questions as honestly as possible, but I need to stress at the outset how conscious I am of the fact that it is all too easy to tidy up and even unintentionally to invent the historical record. I know that some scholars like to tell the story of their intellectual pilgrimage as a series of contingencies, unforeseen developments, one thing unexpectedly leading to another. But with me the danger is the opposite one. I am a terribly tidy person, and what I have to fight against is the desire to produce a story of smooth progression from my original (and, of course, true and important) insights to their elaboration in a sequence of connected and unfolding historical works. In fact I'm aware that my progress has never been linear; it has included many halts as well as a lot of swerving around as a result of trying to accommodate the insights and discoveries of others. So there is no simple story to narrate.

* The date of the interview was 4th October, 2001. 
It helps me a lot, however, that your initial question asks me how I ever became interested in political theory and its history. I find nowadays that, having spent my life as a historian, I cannot manage to offer explanations, or even to think, except in a narrative form. So I'm happy to begin with a narrative, which in my case starts with my schooldays. Among the national examinations that I sat in my final year at school there was one about the history of early-modern England, as a part of which we were expected to read a number of works written in that period. One of the texts we studied was Sir Thomas More's Utopia, on which I have since published a number of articles. ${ }^{1}$ Another was Hobbes's Leviathan, on which I have recently published a book. ${ }^{2}$ I still have the copies of these texts I bought and annotated when I was at school. I sometimes think, when I look back on my career as a scholar, that what I have been trying to do is to find better answers to some of the questions which were originally put to me in those far-off days, and which I didn't understand how to answer at the time.

We didn't study contemporary political theory at school, but I began to do a lot of reading on my own, and one of the books I came across was T. D. Weldon's The Vocabulary of Politics. I still remember how excited I was by its unmasking, as it seemed to me, of the vacuity of much purported political argument. It probably left an indelible mark. What I chiefly remember, however, is my first encounter with the interface between philosophy and history - with the history of philosophy, but also with the philosophy of history. At the time of which I am speaking — the late 1950s - there were still special examinations for entry to Oxford and Cambridge. If you were hoping to take one of these so-called scholarship examinations, you had to stay at school for some extra months and do a great deal of additional reading. I was sitting for a scholarship in History, and we were warned that there was always a special emphasis in that examination on the ability to write about general problems of historical method. So I began to read a number of books on such topics, and I found myself instantly enthralled. One text we were particularly advised to read was R. G. Collingwood's The Idea of History. I was fascinated by it, and I remember looking for others of his works and reading them too, in particular his Autobiography. Another work I found for myself was Bertrand Russell's History of Western Philosophy, 
and I shall never forget the electrifying effect it had upon me, not least because of its exhilarating self-confidence and its glittering prose. For a long time I knew many passages from it almost by heart. I expect that I might disagree nowadays with a number of Russell's historical judgments, but I was reassured as well as excited to find that such a great philosopher took the study of history so seriously, and as a writer of academic prose Russell has always remained a model for me, although he is of course impossible to emulate.

PK \& SS: Could you tell us a little bit about the intellectual scene of the discipline(s) when you first began to research?

QS: I took my BA in History from Cambridge (still the only degree I have 'earned') in June 1962, and was elected to a Fellowship of Christ's College later that summer, a post I have held ever since. I was twentyone years old at the time. I was employed to give tutorials to the students in History at Christ's College, especially those who were specialising in political thought. I should explain that, in studying History at Cambridge it has always been possible to concentrate to a large extent on intellectual history and the history of political thought. I was well taught in these subject myself (by John Burrow, Duncan Forbes and Peter Laslett) so I was not completely ill-prepared as a teacher, although I was of course completely inexperienced. As for my own research, I was not expected by the College to study for a $\mathrm{PhD}$, and consequently never received any formal supervision of any kind. I was trusted to follow my own bent, and insofar as the College authorities had any view of the matter I suppose they simply assumed that I was getting on with it. Which I was, for most of the time, although at that age personal problems tend to loom much larger than intellectual ones.

The intellectual scene, as you nicely call it, appeared at that time a rather barren one to someone primarily interested, as I already was, in political ideas and their history. I had imbibed from Weldon's book the belief that it was absurd of philosophers to suppose that, qua philosophers, they had anything of interest to tell us about moral and political issues, and he exhorted us instead to study the vocabularies in which such issues are formulated. I have always retained something of the scepticism with which he then set about that task. 
For example, he made it seem that our talk about 'rights', and how many rights we may be said to have, is more or less meaningless, falsely assuming as it does that the notion of a right has some ontological grounding when it is merely part of a local ideological practice. I still share that view, and I suppose I have carried such scepticism even further, for it has long seemed to me that the terms in which we express such concepts as freedom, justice, equality and so forth make sense only within the cultural contexts in which they arise, so that questions of the form 'but what does 'justice' or 'equality' really mean' seem to me virtually meaningless. This further thought, however, is a more recent one on my part. What I really need to stress is that, at the time when I was first starting out, the idea of studying normative political theory had been made to seem old-fashioned and slightly absurd.

A further reason why analytical political philosophy seemed of little interest was that a strongly positivistic analysis of the alleged fact-value distinction was still widely credited, at least in anglophone philosophy. Not only were we told that value-judgments were largely a personal matter, but also that there is a realm of the factual that remains 'value neutral'. It had come to seem sensible (what a weird world I am talking about) to concentrate exclusively on the study of facts as opposed to values, with the aim of producing a genuine science of politics. The proper aim of a political theorist was accordingly taken to be that of generating so-called 'empirical theories', which in fact amounted to little more than restatements of existing political practices in more abstract terms. The pressures of the culture were such that I spent far too much time in the early 1960s reading this stuff, and eventually I even published a rather bad-tempered article about empirical theory ${ }^{3}$, but I quickly found that this approach carried no appeal for me at all.

If we turn to the historical study of political theory at that time, we likewise find ourselves surveying an unfriendly landscape. One reason why the history of ideas was so little valued was due to the power of Marxism, not so much as a substantive philosophy but rather as a historical methodology. It's important to remember how extraordinarily influential a materialist approach to the study of history had become in the decades following the Second World War. This was above all the heyday of the Annales School, and in their 
exemplary text, Braudel's massive study of the Mediterranean world in the sixteenth century, we were offered a so-called 'histoire totale' in which economic determinism was in turn incapsulated within a form of geographical determinism, so that (in Braudel's phrase) 'mountains come first'. With geography determining economics, and with economics determining social and political life, there was little space left for the life of the mind except as an epiphenomenon, and it remained virtually invisible in the pages of Braudel's book.

This approach had a baleful effect on the status as well as the methodology of intellectual history. The discipline was either treated as of marginal interest, or else was studied in such a way as to provide alleged evidence in favour of the base/superstucture model itself. A crucial text for scholars of my generation was C. B. Macpherson's The Political Theory of Possessive Individualism, first published in 1962. Macpherson saw seventeenth-century political theory evolving along a single axis, and treated the purported line of development 'Hobbes to Locke' (the subtitle of his book) as a straightforward ideological reflex of an allegedly burgeoning 'bourgeoise' society.

There was a more important reason, however, why the intellectual scene looked unattractive to someone of my interests in the early 1960s. This was due to a widely held view — still held by a number of philosophers - about the point of studying the history of philosophy, and intellectual history more generally. We were taught that there is a canon of classic texts in the history of moral, political, religious and other such modes of thought containing a 'dateless wisdom' in the form of 'universal ideas'. We were further taught that we can hope to benefit directly from investigating these 'timeless elements', since they possess 'a perennial relevance'. These assumptions in turn generated a widely accepted view about how the history of philosophy should be written. We were told to concentrate on the canonical texts, and more specifically on just those portions of the canonical texts in which it is clear that they really are addressing our questions in a 'relevant' way. The outcome was as anti-historical as possible. We were explicitly warned that, if we allow ourselves to become sidetracked into examining the social conditions or intellectual contexts out of which the classic texts arose, we shall lose sight of their dateless wisdom and thereby lose contact with the whole purpose of studying them. 
I spent the opening years of my academic career in a state of frustrated rage against this particular world-order, and I eventually launched a terrorist attack on it in the form of my essay 'Meaning and Understanding in the History of Ideas', published in 1969. (I wrote it between 1966 and 1967, but I had a lot of difficulty getting it published. $)^{4}$ I would never want to write like that now: much of the essay strikes me today as philosophically ill-judged as well as abusive, and when I recently had to revise it for republication I found myself cutting it to half of its original length. But I mention it because it focused in turn on the two orthodoxies I have singled out the 'canonical' and the epiphenomenal approach — and it did its best to discredit or at least to ridicule them.

I must add, however, that a related and far more important publication of 1969 was John Dunn's The Political Thought of John Locke. The Introduction to that work offers a similar (though calmer) account of how the history of philosophy might be written as a genuine history. John also proceeded in the body of his book to practise what he had preached, and thereby succeeded in producing — along with Peter Laslett and John Pocock — the earliest really important work in the so-called Cambridge style.

PK \& SS: Some of your earliest published writings from the 1960s were commentaries upon Hobbes. In 1996 you published a major book titled Reason and Rhetoric in the Philosophy of Hobbes. Could you tell us why Hobbes has been such an important figure in your studies?

QS: My answer closely relates to what I have been saying, for my decision to focus on Hobbes was originally taken for reasons that were methodological as much as historical. I have already mentioned that C. B. Macpherson's book was published in 1962, the year in which I began my research. Macpherson's interpretation gave new prominence to the highly reductionist account of Hobbes's philosophy that Christopher Hill and other Marxist historians of the English revolution had already put into currency. When I first began my research, however, the most important strand in the interpretation of Hobbes's philosophy arose out of the other prevailing methodology of the period. As I have said, this took the form of selecting a text from the canon and subjecting it to a purely internal process of exegesis, with 
the eventual aim of showing what contribution it made to one or other of the perennial issues in political philosophy. Hobbes's political philosophy, above all as articulated in Leviathan, was generally treated as a contribution to thinking about the concept of political obligation. Hobbes was widely viewed at the time as the prototype of a utilitarian, whose view of political obligation was that its grounds and limits are alike determined by calculations of individual self-interest. In 1957, however, Howard Warrender had published a challenging work entitled The Political Philosophy of Hobbes, in which he claimed that Hobbes's theory of obligation takes a deontological form. Specifically, Warrender treats Hobbes's account of our duty to obey the state as an instance of our duty to obey the laws of nature in virtue of recognising them to be the laws of God. This was followed in 1964 by F. C. Hood's book, The Divine Politics of Thomas Hobbes. Hood owed an obvious debt to Warrender, but he made a yet more comprehensive attempt to read Hobbes as the author of a Christian system of politics based on the idea of divine command.

I found myself equally unconvinced by the Marxist and by this purely scripturalist approach to Hobbes's texts, and in one of my earliest articles, published in 1964, I set out to criticise both schools of thought. ${ }^{5}$ Recently I had occasion to re-read this early effort, and I was astonished at the degree of aggression and self-confidence I displayed in this as in others of my early articles, especially as I can't believe that I felt anything like as confident as I tried to sound. I must confess, however, that I rather enjoyed the sustained note of irony I managed to inject into my prose, especially as this is a skill I no longer seem to possess to the same degree.

The objection I tried to develop in my article - and in several others that followed - was that, however plausible Macpherson's or Warrender's readings of Hobbes may appear to someone who merely studies Hobbes's texts, they are historically incredible. Against Macpherson I argued that, if one wants to understand Hobbes's theory of political obligation in Leviathan, what one primarily needs to grasp is not the general economic character of his society at the time. Rather one needs to grasp the way in which the issue of obligation became politically urgent after the execution of king Charles I in 1649 and the demand on the part of the Commonwealth government for every citizen to swear an oath of 'engagement' to its authority. I maintained 
that, when Hobbes argues in Leviathan that obedience and protection are correlative, his aim is to furnish an eirenic solution to this particular crisis of legitimacy, and I added that this is the type of context on which we need to focus if we are to gain a genuinely historical understanding of his work. Against Warrender and Hood I tried to show that this kind of contextual information serves to question their interpretation as well. I maintained that Hobbes's theory of obligation was intended and accepted as a purely pragmatic one, and that it is impossible to understand either the motivation or the reception of his political theory if we take it to be based on a traditional doctrine of Christian natural law.

I turned to Hobbes, in short, as a part of my essentially theoretical task of trying to show that prevailing approaches to the history of philosophy were misconceived. You might still ask, however, why I turned specifically to Hobbes, when the same series of critical points could just as easily have been made by reference to the handling of any of the other major figures in the canon as it was then conceived. There are two answers. One is that I think I must have been influenced by the idea of the canon itself. To British scholars of the period, it seemed obvious that the two great founding fathers of modern political theory were Hobbes and Locke, the first being the leading exemplar of the theory of the State, the second of the theory of popular sovereignty. As I have mentioned, John Dunn, my friend and exact contemporary at Cambridge - to whom I owe an enormous debt for discussing these issues with me throughout the 1960s - was already writing about Locke. So I suppose that left me Hobbes.

My principal reason, however, for focusing on Hobbes arose out of some growing doubts about the idea of the canon itself. At this juncture I need to tell you an anecdote. It concerns Peter Laslett, whose lectures on the history of political theory I had attended with enormous enjoyment as an undergraduate, and whom I met shortly after I took my degree in 1962. Laslett had published his definitive edition of John Locke's Two Treatises of Government in 1960, and I read it instantly at the prompting of my supervisor, John Burrow. Laslett showed that Locke's treatises, which had always been viewed as a celebration of the so-called Glorious Revolution of 1688, had in fact been largely written almost ten years earlier, as a contribution to Shaftesbury's campaign of opposition to the seemingly arbitrary policies of Charles II. 
Talking to Laslett about this scholarly discovery, I was very struck by how he himself saw its wider significance. He felt that he had shown Locke's treatise to be essentially a party-political pamphlet. He took it that, by showing how it had arisen out of a specific political crisis, he had demoted it from the canon by casting doubt on its ahistorical character and significance. As I remember him telling me, he had shown that Locke should not be ranked with such architectonic writers as Hobbes, on whom such an analysis could not be performed.

I felt in a kind of a priori way that there must be some such work of contextualisation to be performed on any text of political philosophy. I'm not sure where that confidence came from, but I suspect that it must have owed a great deal to my reading of Collingwood. If it had a source in the more recent historiography, then it must I think have been J. G. A. Pocock's masterly book, The Ancient Constitution and the Feudal Law, which had been published in 1957. John's book offers a path-finding contextualisation of a number of key figures in early-modern historical and political thought, and it was one of the works I had most enjoyed reading in my undergraduate course. But whatever the source, the outcome was that I conceived the ambition of doing for Hobbes what Laslett had done for Locke. I never succeeded, of course, and I don't in the least mean to compare the essays I went on to write with Laslett's epoch-making piece of scholarship. But this is certainly what primarily caused me to turn my attention to Hobbes. By the beginning of the 1970s I had published an extensive series of articles on his philosophy, concentrating on what I described - to cite the title of one of my essays - as the ideological context of Hobbes's political thought. ${ }^{6}$

PK \& SS: Besides Hobbes, you have studied the Renaissance period of political thought extensively. For some reason this period seems to be rather neglected in standard histories of (political) philosophy (even Machiavelli is seldom counted among the major figures in the history of political philosophy). Why do you think this is?

QS: The neglect of Renaissance philosophy is now beginning to be rectified, but it is certainly true that, when I first began my research, the period was widely ignored. The main reason, I think, carries me back to what I have already said about the way in which the relation- 
ship between philosophy and its history was generally viewed at the time. Philosophy was conceived as a discipline characterised by its preoccupation with a particular range of questions, and political philosophy was characterised (as Isaiah Berlin put it at the time) as a subdiscipline concerned with the question of 'Why should I obey the state?' The history of political philosophy was accordingly taken to consist of a series of texts in which this particular question had been addressed, and various competing answers had been given to it.

I should interpolate a biographical fact at this point. I was appointed to a Lectureship in the history of political theory by the University of Cambridge in 1965, and it thereupon became my duty to deliver a general lecture-course on early-modern political thought. This prompted me to undertake an intensive course of reading in sixteenth century political philosophy to match the reading I had been already doing on the seventeenth century, and it led me in particular to the figure of Machiavelli. What immediately struck me in reading his Principe and especially his Discorsi was that these texts pay almost no attention to questions about our obligation to obey the state or the extent of our right to resist it. They scarcely talk about the concept of the state, and they never make any reference to the concept of a right at all.

This goes a long way, I am sure, to explain why even Machiavelli's philosophy, as you rightly say, was so generally overlooked in histories of political philosophy until recently. My own mood in the mid1960s, however, was such that the reasons usually given for dismissing Machiavelli as of marginal significance seemed to me to be the very reasons for thinking of him as especially worthy of study, and I have never ceased to think and write about his theory of politics since that time. ${ }^{7}$ I was, and I remain, especially interested in theories of freedom that operate without invoking the concept of a right, and Machiavelli's neo-classical analysis of the vivere libero is one of the most interesting and historically influential examples.

PK \& SS: How about the canon of great thinkers in general? Your famous article "Meaning and Understanding in the History of Ideas" was originally a conference paper entitled "The Unimportance of the Great Texts". How do you feel now about "official" canons of western thought? 
QS: I remain ambivalent and perhaps confused in my views about 'the canon'. As I have already indicated, I began with a deep suspicion of the idea, largely I think because I wanted to question the belief that we ought to be focusing on a group of thinkers because of their allegedly timeless relevance to our own interests. As I've said in talking about Hobbes, I wanted instead to try to reconstruct the intellectual contexts in and for which their texts were originally written. To this end, I notice that in my first programmatic essay of 1964 I already spoke about the need to replace the study of individual texts with the study of what I called political discourse, a point on which I subsequently laid much more emphasis after I began reading Foucault's work in the late 1960s.

It seems to me that one of Foucault's many valuable insights relates to the question of how canons come to be formed. Who has the authority to determine what is included and excluded? This is a special case of his broader interest in how, in the construction of modern culture, the question of what counts as knowledge, what should be taught and believed, has been intimately intertwined with questions about legitimacy, and hence with questions about the exercise of social power.

As I have already confessed, however, there is a sense in which the acceptance of the idea of a canon underlay my work from the outset, and certainly helped to determine why I began by working on Hobbes. More recently, moreover, I have become easier in my mind about the reality of a canon of western philosophy. I am less dogmatically reluctant to recognise that there are deep continuities as well as ruptures within our inherited traditions of thought, and that the former are reflected in the fact that leading thinkers have always attended to the works of other and earlier thinkers. I have even ended up by writing a book about Hobbes, although I remain less interested in him as the author of an eponymous system of thought than as a contributor to a number of debates about the Renaissance conception of scientia civilis or civil science.

PK \& SS: It has become a commonplace to stress the influence of British Idealism and especially such figures as Collingwood and Oakeshott in the early development of what later came to be called 'the Cambridge School' of the history of political thought. However, some commentators (Mark 
Bevir, to mention one) have lately paid attention to the strong influence of analytical philosophy in supplying some of the basic categories of the 'Cambridge' approach. Reflecting on your personal experience from the 1960s and 1970s, how would you characterise the influence on the history of political thought of British idealism, on the one hand, and analytical philosophy, on the other?

QS: Here it is hard to be sure, and I can only speak for myself, but I am fairly confident about several points. One is that Michael Oakeshott's philosophical work was of no influence at all. He was widely acknowledged as an illuminating commentator on Hobbes, although I must confess that I found him virtually unreadable on that subject. But if you want to know how he appeared to students of my generation in the 1960s, you would find a very good guide in Brian Barry's book, Political Argument. I don't mean to imply that I could ever have formulated my views on Oakeshott as trenchantly as Brian did in that book, but when I read it I recall agreeing completely. Oakeshott seemed a figure of the past, and we rejected his anti-rationalism and his political conservatism outright. I should add that I always found Oakeshott interesting to talk to, and very generous and encouraging too. But nothing prepared my generation for his apotheosis under Thatcherism, nor the high esteem in which his philosophy continues to be widely held.

R. G. Collingwood was a very different matter. As I've already mentioned, I first read him at school, and when I began my research he was I think the most immediate and powerful influence on the direction of my work. As will be clear to any reader of my essay 'Meaning and Understanding', which you kindly mention, I took directly from Collingwood two methodological injunctions that together informed much of my critique of the history of philosophy as then practised. One was his explicit rejection of the assumption that, in the history of thought, we are looking at a series of different answers to the same questions. Collingwood's insistence in his Autobiography that philosophy is a discipline in which the questions as well as the answers continually change was one that influenced me profoundly, and it's a belief that I have never had occasion to doubt. But there was another and connected injunction from Collingwood's Autobiography that influenced my thinking and practice even more. 
This was his suggestion that we need to approach the study of the past armed with what he called a logic of question and answer. To understand a text or an action, we need to see it not simply as an event but as an attempt to solve a problem. The hermeneutic enterprise is accordingly seen, at least in part, as a matter of trying to recover the problems to which the texts or actions we study can be construed as answers.

Mark Bevir is, however, right to stress that, at least in my own case, the impact of a certain strand of analytical philosophy was of even greater importance, and this too is evident in my essay 'Meaning and Understanding'. Like many of my generation at Cambridge, I was immensely attracted by the figure — or rather the aura — of Wittgenstein. He was our image of philosophical genius, and there was a time when I knew most of the anecdotes in Malcolm's biography by heart. For us Wittgenstein was not the author of the Tractatus, which I have never read with any care, but of the Philosophical Investigations, and I still have the copy of the revised edition I bought as an undergraduate soon after its publication in 1958.

I am sure that I originally bought the Investigations as an act of piety, but after graduating I spent a lot of time reading it, and all the reviews of it I could find, as well as talking intensively to philosophical friends about it. Insofar as I was able to understand the work at all, I took it to be about the theory of meaning, and I carried away from it a basic thought about 'meaning' that subsequently animated all the essays I later published on that theme. The thought is that we should not ask about the alleged 'meanings' of words, but rather about their use, and more specifically about the point of using them in particular ways in particular languagegames. I found very attractive the idea of approaching language essentially as purposeful discourse, and of asking about the different intentions underlying its use in different forms of life. I have never ceased to believe - although it's a commitment on my part that has been widely misunderstood - that intentions and meanings, whether with respect to actions or utterances, are a public matter, and are to be understood not by trying to get into the heads of past actors but simply by observing the forms of life within which they act. I also found appealing the implication that these different arenas or forms of life might be altogether unlike ours, although 
I'm sure that I didn't at the time appreciate the relativistic difficulties into which we readily fall if we embrace such a commitment. I tried to grapple with the problem of conceptual relativism in the $1980 s^{8}$, but in the 1960s it just seemed to me, in the light of the historical research I was already doing, that these aspects of Wittgenstein's vision made a great deal of sense.

By far the most acclaimed English analytical philosopher of the early 1960s was J. L. Austin. He had published little in his lifetime, and he died prematurely, but his reputation for originality and sheer brilliance stood at its zenith when How To Do Things with Words was posthumously issued in 1962. I still possess the copy I bought a year later, and I still remember how astonished I was when I first read it. Partly, I think, I was entranced by the world of fine linguistic distinctions into which I was drawn, for I have always retained — perhaps from having studied so much Latin at school - a pedantic interest in the niceties of grammar and usage. But I think I was mainly taken with Austin's work because his philosophy of language seemed to me to flow so naturally from that of Collingwood and Wittgenstein. This will perhaps seem a strange thing to say, however, so let me try to explain a little more.

As I have already stressed, what seemed to me most illuminating in Collingwood was his proposal that we should try to recover the questions to which the texts we study can be construed as answers. But another way of putting that point would be to say that we should think of such texts as parts of a continuous dialogue - as developments, or criticisms, or repudiations of earlier positions - and should therefore ask ourselves what their authors were doing in writing as they wrote. How far, that is, were they developing earlier insights, or criticising them, or repudiating them, and so on. Now, this use of language to do things was what Austin above all highlighted. So I saw quite a close kinship between Collingwood's and Austin's approaches. Since then I have wondered about the possibility of a biographical relationship as well. Austin must surely have been a student at Oxford when Collingwood was Professor of philosophy there? But I don't know of any historian of philosophy who has pointed out the possible implications of that fact.

I mainly thought of Austin's philosophy, however, as an appendix to Wittgenstein. Wittgenstein had instructed us to think about the 
use of language, and it appeared to me that Austin in effect picked up this suggestion and ran with it. The outcome was a wonderfully precise anatomy of what might be meant by talking about the enormous range of uses to which language can be put, and hence the range of things that can be done with it. I should add that, rightly or wrongly, I similarly regarded Paul Grice's theory of meaning as an appendix to Austin, treating Grice's analysis of communicative intentions as a further analysis, in effect, of Austin's pivotal notion of an illocutionary act.

I went on to publish a series of articles on meaning and speech acts in the late 1960s and early 1970s, ${ }^{9}$ and on re-reading them recently I found that they owe an overwhelming debt to Wittgenstein, Austin and Grice. So I think that — to end by answering your question directly - Mark Bevir is undoubtedly right to suggest that the main influences on my own work in the theory of interpretation came directly from the mainstream of analytical philosophy.

PK \& SS: Looking backwards, a striking feature of political theory at large in the late 1960s and early 1970s seems to have been a strong confidence in the development of new methodologies and theoretical frameworks and their ability to liberate political theory and its history from a number of traditional liabilities. As J. G. A. Pocock wrote in 1971, "what we can claim to be living through is nothing more or less than the emergence of a truly autonomous method, one which offers means of treating the phenomena of political thought strictly as historical phenomena ... we are beginning to see historical daylight." 10 After thirty years, what thoughts does this kind of optimism bring into your mind?

QS: I am very glad that you single out John Pocock's name. As I've already mentioned, he was a major influence on my own theory and practice when I was first starting out, and he has remained a generous commentator on my work ever since. The main influence he exercised over my more theoretical work stemmed from an article he published as early as 1962 on the different 'levels of abstraction' at which different political thinkers work. I have sometimes wondered if this formulation may also have owed something to Collingwood, but in any case it was a further contribution that gave me the confidence to insist that we should be approaching the texts we study rather nominalistically, assuming that 
each is addressing its own questions rather than assuming that they are engaged in some common enterprise.

It is true that John's historical work has always been slightly different in idiom from mine. He seems to me to incline - most obviously in his masterpiece, The Machiavellian Moment - towards a kind of structuralist intellectual history. He stresses the power of language to constrain our thoughts, whereas I tend to think of language at least as much as a resource to be deployed. But there is no doubt that our approaches converge, and there is equally no doubt that, as you imply, we had both acquired, by the early 1970s, a considerable confidence in the theoretical approach we had by then worked out.

I still think that some at least of this confidence was not ill-founded. Let me give you two examples. Consider first the view - widely prevalent in the 1960s, as I have said - that ideologies are essentially epiphenomena of underlying socio-economic realities. I was one of many who pointed out - and here Alasdair MacIntyre's work on the philosophy of action influenced me greatly - that all ideologists are obliged to use a pre-existing normative vocabulary to legitimise their activities, and thus that the question of what they can hope to achieve depends in part on how they can hope to describe what they are doing. But to say this is to say that all ideologists are obliged to some degree to tailor their projects to fit the evaluative language of their day. And to say this is to say in turn that such preexisting moral structures, and the vocabularies in which they are formulated, can hardly be mere epiphenomena. Rather they must act as constraints on what can be legitimised, and thus on what can be done. I remain of the view that this is basically the right way to think about the relations between ideologies and social change. I can't forbear from adding that nowadays this view is widely shared. This is a battle that was won.

I feel a similar confidence about my views on the point or purpose of studying intellectual history. I would still want to stress the negative point on which I so much insisted in the 1960s. I still think it misguided to seek a justification for the subject in an attempt to show that the great philosophers of the past were addressing our questions, and that they are worth studying insofar as they can be shown to think about those questions as we do. Here too I can't forbear from adding that, although I called down a storm of abuse 
upon my head when I presented this argument in my 'Meaning and Understanding' essay, this view has likewise come to be widely shared. Nowadays the history of philosophy is far more widely written as genuine history, that is, as an account of an activity as it was actually carried on in the past.

I accept, however, that there was at the same time something overconfident about my youthful pronouncements. Let me again single out two points. One is that I no longer feel quite so sure about identifying the historical meanings of texts, nor am I even happy about talking in such terms. I feel strongly the force of Gadamer's point that we can hope to see in the texts we study only what we are permitted to see by the horizons of our own culture and the pre-judgments built into it. I ought to add, however, that I feel liberated by what may at first sound like a greater scepticism. I used to think far more in terms of correct interpretations, and to suppose that there is usually a fact of the matter to be discovered. I now feel that, because the texts we study and what seems important in them will always change as our own society changes, the process of interpretation is a never-ending one. The texts we study continually alter their contours as we put them in new contexts and relate them to different texts. There is always something new to be learned.

My other point is that I used to speak too readily about identifying the doctrines espoused by the writers of the texts we examine. I have never believed that the meanings of texts are to be equated with the intended meanings of their authors. But I certainly used to show an insufficient awareness of the extent to which the writers of the texts we study are in less than full control of what they write. Here I have been influenced by what I take to be one of the most valuable insights of deconstructionist criticism. The insight I have in mind is that what passes for argument in philosophical texts often proves on more sceptical inspection to amount to little more than a tissue of metaphors and other rhetorical devices employed to lend authority to what is asserted. This helps to explain why, since the 1980s, I have spent so much time studying the classical and Renaissance art of rhetoric. ${ }^{11}$ It also helps to explain why, in a further revision of my earlier approach, I have become so much more attentive to the genres to which individual texts are couched, and the nature of the linguistic codes and conventions embodied in them. 
I need to end by underlining, however, that I wouldn't want to accuse John Pocock, or even my own younger self, of a generalised over-confidence. It's hard nowadays to recapture just how unsatisfactory so much intellectual history was a generation ago, and John was undoubtedly justified in believing that he had something new and better to say at the level of method as well as of practice. As for me, my confidence has always been limited by the limited nature of my enterprise. I have always stressed that the approach I commend is addressed only to those who are interested in trying to recover the historical identity of philosophical texts. But of course you can do all sorts of things with such texts besides trying to understand them. You can seek solace in them, you can deconstruct them, you can paper the walls with them if you like. I have never been an enemy of such pluralism; I have simply been talking about something else.

PK \& SS: One of your major works, The Foundations of Modern Political Thought (1978) was published before the distinction 'foundationalist/ antifoundationalist' became so highly popular in the study of political philosophy. As often happens, later terminological developments have created a need to comment upon earlier ones. James Tully and Kari Palonen, for example, have spoken about the historically contingent and philosophically antifoundationalist nature of the 'foundations' you describe in your two volumes. Consequently, they suggest that the title is intended to be ironic. On the other hand, if one thinks of the intellectual context of the 1970s, one cannot wholly avoid the idea that the term 'foundations' might carry with it some of the era's theoretico-methodological optimism. In this light, your study could be said to aim at genuine 'foundations of modern political thought' in that it was a serious attempt to present the most reliable historical knowledge available at the time about the early development of modern political thought. How would you comment upon these speculations about the goals of your work?

QS: I have always been an anti-foundationalist, although it is true (as you rightly observe) that this particular piece of jargon was not yet current in the 1960s. I have always assumed — and I say this explicitly in one of my early essays - that positivism failed in its project of building a structure of empirical knowledge on foundations independent of our judgments. ${ }^{12}$ (One of my review-articles of the 1970s was 
even entitled 'The flight from positivism'.) ${ }^{13}$ I read Thomas Kuhn's Structure of Scientific Revolutions very soon after it came out in 1962 and was deeply impressed by it. I'm bound to say, though, that it shocked me less than it shocked some others, if only because it seemed to me that Kuhn's attempt to replace foundationalism with talk of paradigms sounded very much like Collingwood's talk about the 'absolute presuppositions' characteristic of any epoch of thought. I should mention too that I was very excited by the all-out attack on foundationalism launched by Richard Rorty in his Philosophy and the Mirror of Nature in 1979 , and I'm proud to say that I gave that book one of its earliest and most admiring reviews. ${ }^{14}$

My anti-foundationalist allegiances go still deeper. I was a member of the Institute for Advanced Study at Princeton between 1974 and 1979, and it was during that period that I completed my book, The Foundations of Modern Political Thought. Those were the years in which I got to know Dick Rorty. He was then a member of the Philosophy Department at the University, and he helped me greatly by reading and discussing with me the theoretical work I was trying to do at that time. But the Institute itself was a veritable hotbed of antifoundationalism. Tom Kuhn was in the next-door office, and he and I talked a lot about the new work he was trying to do on the theory of meaning to match his thesis about incommensurability. A few doors along was the leader of the social theory group of which I was a member, Clifford Geertz, whose pluralist and even relativist theory of culture has arguably been the most influential statement of antifoundationalism in recent social science.

I mention all this by way of stressing that anti-foundationalism was in my blood at the time, so that it was neither deliberately oldfashioned nor purely inadvertent on my part to have named my book as I did. Nor was the title ironic, although I make that further claim with hesitation, if only because Jim Tully and Kari Palonen are the two commentators on my work who always seem to understand my projects better than I understand them myself. But as I see it, my reasons for invoking the metaphor in my title were very much along the lines you suggest. I was trying to identify the most basic concepts out of which we in the modern west constructed the legitimising theories we continue to deploy in talking about the duties of citizens and the rights of states. The first volume of my book focused 
on theories of civic virtue and self-government; my second focused on the rise of absolutism and the emergence of rival theories of natural rights. These, I tried to show, were the conceptual foundations on which we in the modern west went on to build the theory of the state.

I now recognise, however, that there was something unfortunate about my metaphor. I undoubtedly had in mind Donald Kelley's brilliant book, published in 1970, on the rise of historical jurisprudence, which he had called Foundations of Modern Historical Scholarship. His omission of the definite article was surely deliberate, but so too was my decision to include it in my own title, thereby laying claim to something more definitive. But Don was surely right and I was surely over-assertive. Where I think we were both wrong was in using a metaphor that virtually commits one to writing teleologically. My own book is far too much concerned with the origins of our present world when I ought to have been trying to represent the world I was examining in its own terms so far as possible. But the trouble with writing early-modern European history is that, although their world and our world are vastly different from each other, our world nevertheless somehow emerged out of theirs, so that there's a very natural temptation to write about origins, foundations, evolutions, developments. But it's not a temptation to which I would ever think of yielding in these post-modern days.

There's one merit, however, that I would still wish to claim for my title. It's as straightforwardly descriptive as I could manage to make it. I still retain the distaste I felt at the time for the kind of flowery titles that give one no sense of the contents of the book. Consider, for example, John Wallace's pioneering study, Destiny his Choice. It's a wonderful book, and its analysis of loyalism in the English revolution influenced my own historical work greatly. But you would never guess, from its title, that it is basically a study of the poetry of Andrew Marvell. That seems to me a serious weakness, and one worth trying to avoid, although such titles have since become even more popular, especially in the United States.

PK \& SS: Moving to your more recent works, some commentators on Liberty Before Liberalism (1998) have complained about - or applauded - what they see as the 'programmatic' nature of the book. In this context, 
the comparison made in the book between Neo-Roman Republicanism and the present liberal hegemony is frequently mentioned. To what degree should the message of the book really be read as a political programme?

QS: I need to introduce a distinction here which I have always tried, although not always successfully, to keep before me in my work. On the one hand, I freely admit - in fact, I want to emphasise - that moral and political motivations have always affected my choice of subjects for research. On the other hand, I very much hope that they have not affected the way in which I then approach and treat those subjects. I want my work to be as historical as I can possibly make it, but I also want it to have some political point.

Let me take as an example my discussion, in the book you kindly mention, between Thomas Hobbes and James Harrington over the question of how to understand the concept of political liberty. ${ }^{15}$ I try to reconstruct the terms and the motivations of the debate so far as possible from the point of view of the protagonists. I try to show how Hobbes's analysis of freedom as mere absence of external impediment was designed to refute and replace a neo-classical theory which, according to Hobbes, had helped to cause the English civil wars. I then try to show that, when Harrington declared that freedom of action is also limited by background conditions of domination and dependence, he was attempting both to respond to Hobbes and to restate a neo-classical theory as a part of his argument in favour of creating a genuine English republic.

My basic aim in my book was thus to reconstruct the terms and motivations of an early-modern argument. But one of my reasons for wanting to reconstruct the argument is that it seems to me worth reconsidering. Modern liberal political theorists largely agree with Hobbes about the idea of freedom; Harrington's vision has for long been dismissed as confused. But is it confused? Or does his analysis capture something important that Hobbes forgets (or deliberately underplays)? Once we see what is at stake, we can begin to think again about the issues they discussed. My own view, moreover, is that as soon as we do so we begin to see two things that modern liberal theorists have sought to conceal from us. One is the ideological character of their purportedly value-neutral analysis of freedom. The other is that, in attempting to discredit those who were arguing 
for greater public participation in government in the name of greater liberty, they have missed an important dimension of thinking about freedom that needs to be restored.

I admit that I am walking a tightrope. As with all tightropes, moreover, it is possible to fall off on one side or the other. It seems to me that most historians fall off on the side of worrying too little about the point of what they are doing. I am more in danger of falling off in the direction of sacrificing historicity. If the choice is between historical impurity and moral pointlessness, then I suppose that in the end I am on the side of the impure. But I see myself fundamentally as an historian, so that my highest aspiration is not to fall off the tightrope at all.

PK \& SS: Carrying on from the previous question, in your early writings you seem to be rather strict about the relations between the history of ideas and the present. You wrote that we have to learn to think for ourselves and should not go on looking to our ancestors for direct answers to our questions. How do you see this relation now? What is the point of historical studies?

QS: I have slightly softened my stance. As I conceded earlier, I find more in the way of a tradition and thus of intellectual continuity than I used to find in the history of moral, social and political thought. So I see more prospect than I used to see in arguing illuminatingly with our elders and betters over some at least of the key concepts that continue to structure our common life.

I need, however, to enter two caveats. One is the warning I have just been issuing to myself. If we are too importunate about wanting our forebears to speak directly to us, we run the risk of pulling their arguments out of shape and thus of losing contact with what they actually thought. The other caveat is that, even if we manage to avoid that danger, we must not confuse the project of mounting such a dialogue with the project of gaining a historical understanding of our forebears' thought. To understand someone else's beliefs, you need to attend not merely to what they say; you also need to find some means of discovering what they saw themselves as doing in saying what they said. If we merely seek a dialogue with the past, we leave ourselves no space to engage in this further hermeneutic enter- 
prise. But it is indispensable to engage in it if we want a historical understanding of the character of anyone's thought.

You ask about the point of our historical studies, and I'm grateful to you for putting the question so sharply. As you can already see, it's a question that, in my view, historians need to ask themselves more urgently than they commonly do. No doubt we need some historians simply to be story-tellers, and the power of our history to shape our identities is not to be underestimated, although the power of propagandists and politicians to construct that history to suit their own purposes needs no emphasis either. Nor do I want to question the obvious fact that many of us feel a natural curiosity about the artifacts of earlier cultures and rightly want historians to satisfy that curiosity. I have a particular passion, for example, for the buildings as well as the philosophy of early-modern Europe, and I was even tempted at an early stage in my career to think of becoming a historian of architecture. But for me it has never been enough to say that the historian is the name of the person who helps to satisfy our natural curiosity about the world we have lost. Perhaps I lack the true historian's sensibility, but I have always wanted the study of the past to be of some use to us here and now, and this desire increasingly guides my practice.

It may seem inconsistent to stress this point, since I have always tried to write about the need to treat the past as a foreign country and to see things from their point of view. But there is no incompatibility, for it seems to me that some of the most useful lessons we can hope to learn from the history of philosophy stem from the fact that past thinkers often thought in a manner altogether alien to us. Nor is this simply a matter of widening our cultural horizons and becoming less parochial in our attachment to our inherited beliefs. We may also find, as a result of our historical or ethnographic enquiries, that some of what we currently believe about our moral or political arrangements turns out to be directly questionable. We are prone, for example, to think that the concept of individual responsibility is indispensable to any satisfactory moral code. But A. W. H. Adkins's analysis of ancient Greek values serves to challenge that belief. We are prone to think that there can be no concept of the state in the absence of centralised systems of power. But Clifford Geertz's study of classical Bali shows how the one can flourish in the absence of the 
other. The alien character of the beliefs we uncover constitutes their 'relevance'. Reflecting on alternative possibilities, we provide ourselves with one of the best means of preventing our current moral and political theories from degenerating too easily into uncritically accepted ideologies. At the same time, we equip ourselves with a new means of looking critically at our own beliefs in the light of the enlarged sense of possibility we acquire.

PK \& SS: You have a reputation for being adamant when it comes to anachronistic interpretations of the past. You are well known (at least in Finland) for "Quentin Skinner's famous prohibition of anachronism". By that is usually meant the phrase "No agent can eventually be said to have meant or done something which he could never be brought to accept as a correct description of what he had meant or done" from your "Meaning and understanding". This has probably led some people to hold views according to which the main object of your methodological programme is to "avoid anachronisms at all costs" (e.g. Jonathan Rée seems to suggest something like this in his "Vanity of historicism" article). ${ }^{16}$ Yet you use the concept of "anachronism" very rarely in your writings. Would you like to clarify your views on anachronisms in intellectual history?

QS: You are right to say that I rarely complain about the dangers of anachronism in explicit terms. But to me anachronism is nevertheless a sin, and I have written at different times about two related ways in which the sin is frequently committed. They both stem from the wicked assumption that philosophy concerns itself with a certain determinate range of puzzles, and that the history of philosophy, if it is to be of any use to us, must therefore concern itself with the contribution made by past thinkers to the solution of those puzzles.

One danger to which this commitment gives rise is that of anachronistically translating into our vocabulary the terms in which past thinkers phrased the problems they discussed. For example, we remain interested in the question of whether the fostering of civic virtue is a necessary condition of maintaining effective citizenship. If we study the history of classical or Renaissance philosophy, we find it suffused with discussions about virtus, and it becomes all too easy to suppose that this term can best be translated as 'virtue', thereby enabling us to read off the views held by classical and Renaissance 
philosophers about the question that interests us. My own view is that the term virtus, as used by Roman and Renaissance theorists of self-government, has no single-term translation into modern English at all, nor even any manageable paraphrase. To understand the term, we need to see it as an element in the very unfamiliar language-games in which it was originally employed, and to trace its relationship with many other terms - terms such as fortuna, gloria and libertas. To grasp its 'meaning' is a matter of seeing its place and function within such networks, not a matter of trying to place it within our own very different networks. Our aim should be to draw a map of a foreign country, not to see how far that country may happen to match the shape of our own.

My other worry about anachronism stems from the suspicion I have always felt towards what Lyotard and his followers call metanarratives. There is a danger of conscripting individual thinkers into stories of our own making, and thus of making them contribute to grand narratives of which they had no awareness. I wrote at length about this form of anachronism in my essay on 'Meaning and Understanding' and gave a number of examples. Did Marsilius of Padua have a doctrine of the separation of powers? Did Sir Edward Coke articulate a theory of judicial review? Were the Levellers in the English revolution democrats? Was John Locke a liberal? My point in the passage you quote from my article was that, in all these cases, the question is phrased in terms unavailable to the writers concerned. The arguments they advanced are ripped from the context of their occurrence and made to contribute to a story about which they knew nothing. So whatever answers we give to such questions, they cannot be accounts of anything that the writers in question meant by what they said. We can ask these questions if we like, but to me they seem so anachronistic as to be pointless.

PK \& SS: If you look at the study of intellectual history at the moment, are there any specific dangers confronting the field that you worry about? Do you still see some undesirable methodological orthodoxies around and how do you see your own authority/influence in this respect? Which directions of research do you find the most exciting? How about the so-called Begriffsgeschichte? How would you relate your own studies and methodological views to this tradition? 
QS: The world is not organised precisely as I should like it to be, and this makes it easy to echo what you say and speak in gloomy terms about undesirable orthodoxies. The assumption that the great philosophers of the past are only of interest if they can be shown to be addressing our questions is an undesirable orthodoxy that dies very hard, and in my view it still governs far too many contributions to the field. We also have to contend with the criticism that we ought not, in any case, to be studying the thoughts of an elite of dead white European males. I certainly feel gloomy when I encounter that form of condescension, and it doesn't seem to me any the less philistine for being directed against the educated. I also feel a certain gloom about two divergent trends in our recent culture. On the one hand, the serious study of the past is imperilled by the post-modernist disposition to glory in making a mélange of ideas and images with deliberate disregard for the context of their occurrence. On the other hand, we live in reactionary times, and the willingness to hijack the great names of the western intellectual tradition as a way of denouncing modernity continues unabated, especially among some of the followers of Leo Strauss.

When I reflect on the field of intellectual history, however, I don't in general feel gloomy at all. Rather, I feel optimistic and pleased. The demise of Marxism as a historical methodology means that no one nowadays treats people's beliefs as mere epiphenomena of allegedly more 'real' processes. The field of intellectual history has greatly developed in recent times, and brilliant work is being done in new areas, perhaps especially in the history of scientific ideas, in which the cultural construction of what counts as knowledge has been very fruitfully explored. The work of feminist historians and philosophers has added a whole new dimension to the subject, as well as transforming the way in which many traditional topics are approached. The fashion for deconstruction has bequeathed a valuable legacy in making us more self-aware about the implications of the fact that philosophical texts are at the same time literary artifacts. The whole field is immensely more alive and exciting than it was when I first entered it, and the volume of outstanding scholarship being published is truly exhilarating.

You ask specifically for my views about Begriffsgeschichte, the study of the history of concepts initiated by Reinhart Koselleck and his associates. I admit to a faint anxiety that this could become another way of taking concepts and their expression out of the contexts that 
make sense of them and inserting them into an anachronistic kind of story of our own construction. But so long as this danger can be avoided, then I see every reason to welcome the attempt to write histories of concepts - or rather, as I strongly prefer to put it, to write histories of the uses of concepts in argumentation. I have even tried to operate in this idiom myself, writing a history of debates about the concept of liberty in my most recent book, and a history of the acquisition of the concept of the state in the book I currently have in the press.

PK \& SS: Finally, when you take a look at your long-lasting university career, how do you think your thoughts have changed in these years (e.g. is there a true "rhetorical change or shift"?) Which of your works do you find the dearest?

QS: I've tried to indicate as I've gone along a number of ways in which my views have changed over the years. I don't think I can hope to summarise the shifts with reasonable brevity, if only because there have been rather a lot of them. But I need to stress that I am not at all ashamed of having changed my mind in various ways. Some of my critics have found it frustrating and even disgraceful that I have altered the emphasis and even the direction of some of my arguments. But it would surely be even more disgraceful if I had not shifted at all in a lifetime of trying to read and think about the many ways in which our society reacts to its own past.

It is very kind of you to end by asking me, in your fine phrase, which of my works I find the dearest. It happens that you are asking me this question at a good moment, and I should like to try to answer, although I must be careful not to end on too blatantly selfindulgent a note.

I have never been able to bring myself to re-read any of my works after their publication, so until recently I should not have known how to respond to the question you ask. But I was obliged several years ago to overcome this fastidiousness when I made an agreement with the Cambridge University Press to revise and republish some of my articles. I completed the process of revision earlier this year, and the resulting book will be published in three volumes this summer under the general title Visions of Politics. The first volume, Regarding 
Method, brings together my philosophical articles, on which we have mainly concentrated in this interview. The second, Renaissance Virtues, contains quite a lot of new material - including the essay I have mentioned on the concept of the state - but also collects a number of essays I have published over the years about early-modern ideals of republican self-government. The last volume, Hobbes and Civil Science, also contains some new work, together with heavily revised versions of the early articles I published about Hobbes's theory of political obligation and civic rights.

To assemble these volumes, I had to re-read everything I have ever published in the way of journal-articles and chapters in books. So I am well-placed — for the first time in my career — to answer your question. I have to admit that in the case of some of my essays I decided that they ought not to be republished at all. Many of the others - especially my early pieces - needed so much revision that, although I am republishing some of them, they amount in their new form to new works. However, some of my early work was not only better than I had remembered, but in some cases seemed worth republishing more or less without change. Among my philosophical essays, by far the best is the one I published in 1979 under the title 'The Idea of a Cultural Lexicon', in which I try to talk about the relations between language and social change. ${ }^{17}$ The historical essay in which I manage most successfully to make my point about the usefulness of studying theories contrasting with our own is the one I published in 1984 in the volume on the history of philosophy I coedited with Dick Rorty and Jerry Schneewind. ${ }^{18}$ Finally, the essay in which I am most successful in making my point about the need to recover what writers are doing as well as what they are saying is the one I published in 1991 on Hobbes's theory of political liberty. ${ }^{19}$ The rest is silence.

\section{Notes}

1 'More's Utopia', Past and Present 38 (1967), pp. 153-68; 'More's Utopia and the Language of Renaissance Humanism' in The Languages of Political Theory in early-Modern Europe, ed. Anthony Pagden (Cambridge, 1986), 
pp. 123-57; 'The Lessons of Thomas More', The New York Review of Books, 14 August 1978, pp. 57-60.

${ }^{2}$ Reason and Rhetoric in the Philosophy of Hobbes (Cambridge, 1996).

3 'The Empirical Theorists of Democracy and their Critics: A Plague on Both Their Houses', Political Theory 1 (1973), pp. 287-306.

4 'Meaning and Understanding in the History of Ideas', History and Theory 8 (1969), pp. 3-53.

5 'Hobbes's Leviathan', The Historical Journal 7 (1964), pp. 321-33; see also 'Warrender and Skinner on Hobbes: A Reply', Political Studies 36 (1988), pp. 692-95.

6 'Hobbes's Leviathan', The Historical Journal 7 (1964), pp. 321-33; 'History and Ideology in the English Revolution', The Historical Journal 8 (1965), pp. 151-78; 'Hobbes on Sovereignty: an Unknown Discussion', Political Studies 13 (1965), pp. 213-18; 'Thomas Hobbes and his Disciples in France and England', Comparative Studies in Society and History 8 (1966), pp. 153-67; 'The Ideological Context of Hobbes's Political Thought', The Historical Journal 9 (1966), pp. 286-317; 'Thomas Hobbes and the Nature of the Early Royal Society', The Historical Journal 12 (1969), pp. 217-39; 'Conquest and Consent: Thomas Hobbes and the Engagement Controversy' in The Interregnum: The Quest for Settlement, ed. G. E. Aylmer (London, 1972), pp. 79-98.

${ }^{7}$ See The Foundations of Modern Political Thought, Volume I: The Renaissance (Cambridge, 1978); Machiavelli (Oxford, 1981); 'Machiavelli on the Maintenance of Liberty' Politics 18 (1983), pp. 3-15; 'The Idea of Negative Liberty: Philosophical and Historical Perspectives' in Philosophy in History, ed. Richard Rorty, J. B. Schneewind and Quentin Skinner (Cambridge, 1984), pp. 193-221; 'Ms Machiavelli', The New York Review of Books, 14 March 1985, pp. 29-30; 'Introduction' to Niccolò Machiavelli, The Prince, ed. Quentin Skinner and Russell Price (Cambridge, 1988), pp. ix-xxiv; 'Machiavelli's Discorsi and the Pre-humanist Origins of Republican Ideas' in Machiavelli and Republicanism, ed. Gisela Bock, Quentin Skinner and Maurizio Viroli (Cambridge, 1990), pp. 121-41; 'Machiavelli's Political Morality' European Review 6 (1998), pp. 321-5.

${ }^{8}$ See 'A Reply to my Critics' in Meaning and Context: Quentin Skinner and his Critics, ed. James Tully (Cambridge, 1988), pp. 235-59.

9 'Conventions and the Understanding of Speech Acts', The Philosophical Quarterly 20 (1970), pp. 118-38; 'On Performing and Explaining Linguistic Actions', The Philosophical Quarterly 21 (1971), pp. 1-21; "Social Meaning" and the Explanation of Social Action' in Philosophy, Politics and Society, Series IV, ed. Peter Laslett, W. G. Runciman and Quentin Skinner (Oxford, 1972), pp. 136-57; 'Motives, Intentions and the Interpretation of Texts', New Literary History 3 (1972), pp. 393-408. 
${ }^{10}$ J. G. A Pocock, 'Languages and Their Implications: The Transformation of the Study of Political Thought' in Politics, Language, and Time (New York, 1971), p. 11.

11 'Thomas Hobbes: Rhetoric and the Construction of Morality', Proceedings of the British Academy 76 (1990), pp. 1-61; 'Scientia civilis in Classical Rhetoric and in the Early Hobbes' in Political Discourse in Early-modern Britain, ed Nicholas Phillipson and Quentin Skinner (Cambridge, 1993), pp. 67-93; 'Moral Ambiguity and the Renaissance Art of Eloquence', Essays in Criticism 44 (1994), pp. 267-292; Reason and Rhetoric in the Philosophy of Hobbes (Cambridge, 1996); 'Rhetoric and Conceptual Change', The Finnish Yearbook of Political Thought, 3 (1999), pp. 60-73.

12 'Hermeneutics and the Role of History', New Literary History 7 (1975), pp. 209-32.

13 'The Flight from Positivism', The New York Review of Books, 15 June 1978, pp. 26-8.

${ }^{14}$ 'The End of Philosophy?' The New York Review of Books, 19 March 1981, pp. 46-8.

${ }^{15}$ Liberty before Liberalism (Cambridge, 1998), pp. 6-10, 84-6.

${ }^{16}$ Jonathan Ree, 'The Vanity of Historicism' New Literary History 22 (1991), pp. 961-83.

17 'The Idea of a Cultural Lexicon', Essays in Criticism 29 (1979), pp. 20524.

${ }^{18}$ 'The Idea of Negative Liberty: Philosophical and Historical Perspectives' in Philosophy in History, ed. Richard Rorty, J. B. Schneewind and Quentin Skinner (Cambridge, 1984), pp. 193-221.

19 'Thomas Hobbes on the Proper Signification of Liberty', Transactions of the Royal Historical Society 40 (1990), pp. 121-151. 